\title{
Combining Carbon Nanotubes and Chitosan for the Vectorization of Methotrexate to Lung Cancer Cells
}

\author{
Giuseppe Cirillo ${ }^{1,2}, * \mathbb{C}$, Orazio Vittorio ${ }^{3,4,5}$, David Kunhardt ${ }^{1}$, Emanuele Valli ${ }^{3,5}$, Florida Voli ${ }^{3}$, \\ Annafranca Farfalla ${ }^{2}$, Manuela Curcio ${ }^{2}$, Umile Gianfranco Spizzirri ${ }^{2}{ }^{(1)}$ and Silke Hampel ${ }^{1}$ (I) \\ 1 Leibniz Institute of Solid State and Material Research Dresden, 01069 Dresden, Germany \\ 2 Department of Pharmacy, Health and Nutritional Sciences, University of Calabria, 87036 Rende (CS), Italy \\ 3 Children's Cancer Institute, Lowy Cancer Research Centre, UNSW Sydney, NSW 2031, Australia \\ 4 ARC Centre of Excellence for Convergent BioNano Science and Technology, Australian Centre for \\ NanoMedicine, UNSW Sydney, NSW 2052, Australia \\ 5 School of Women's and Children's Health, Faculty of Medicine, UNSW Sydney, NSW 2052, Australia \\ * Correspondence: giuseppe.cirillo@unical.it; Tel.: +39-0984-493011
}

Received: 28 June 2019; Accepted: 4 September 2019; Published: 6 September 2019

check for updates

\begin{abstract}
A hybrid system composed of multi-walled carbon nanotubes coated with chitosan was proposed as a $\mathrm{pH}$-responsive carrier for the vectorization of methotrexate to lung cancer. The effective coating of the carbon nanostructure by chitosan, quantified ( $20 \%$ by weight) by thermogravimetric analysis, was assessed by combined scanning and transmission electron microscopy, and X-ray photoelectron spectroscopy (N1s signal), respectively. Furthermore, Raman spectroscopy was used to characterize the interaction between polysaccharide and carbon counterparts. Methotrexate was physically loaded onto the nanohybrid and the release profiles showed a $\mathrm{pH}$-responsive behavior with higher and faster release in acidic ( $\mathrm{pH}$ 5.0) vs. neutral ( $\mathrm{pH}$ 7.4) environments. Empty nanoparticles were found to be highly biocompatible in either healthy (MRC-5) or cancerous (H1299) cells, with the nanocarrier being effective in reducing the drug toxicity on MRC- 5 while enhancing the anticancer activity on H1299.
\end{abstract}

Keywords: multi-walled carbon nanotubes; nanohybrids; methotrexate; $\mathrm{pH}$ responsivity; lung cancer

\section{Introduction}

Lung cancer, one of the most common forms of cancer, is currently the leading cause of cancer-associated death worldwide [1,2]. It can be divided into two types, namely, small-cell lung carcinoma (SCLC) and non-small-cell lung carcinoma (NSCLC) [3-6], with the asymptomatic early-stage malignancy being responsible for locally advanced or metastatic disease at the time of diagnosis and a poor five-year survival rate (7\% and $21 \%$ for SCLC and NSCLC, respectively) $[7,8]$.

Although surgery has a major role in the survival of early-stage-cancer patients [9], chemotherapy is still needed to alleviate symptoms and prolongue life [10]. The physiological and pathological features of the organ, together with high variability of the tumor microenvironment, are the main obstacles to the chemotherapeutic treatment of lung carcinomas [11,12], with the insurgence of severe side effects and resistance by cancer cells dramatically limiting the performance of the different therapeutic agents employed in clinics [13].

Consequently, many different delivery methods have been explored as non invasive formulations for a selective and personalized therapy able to optimize the pharmacological efficacy of conventional cytotoxic drugs [14-17]. Great hope is placed on the role that nanotechnology can help to achieve these results, and different types of nanoparticle systems showed promising results as cancer theranostics [18-20]. 
In particular, carbon nanohybrids, consisting of carbon nanostructures (hexagonal $\mathrm{sp}^{2}$-bonded carbon atoms) functionalized with different types of polymers from both synthetic and natural origin, are receiving increasing attention by researchers due to their superior physical, chemical, and biological features [21-28]. Among others, the high specific surface area, the ability to be internalized within cells via passive diffusion and/or endocytosis, and the high drug loading capability due to their rod-like shape, made carbon nanotubes (CNT) an interesting material for the preparation of diagnostic and therapeutic devices [29-32]. Nevertheless, the great concerns about CNT toxicity, mainly ascribed to their hydrophobic and shape patterns, and resulting in inflammation and alteration of the cellular redox state, generated a debate and reducing their applicability in biomedicine [33-35]. The surface functionalization with hydrophilic polymeric materials, increasing CNT water affinity [36-40], was proposed as a valuable approach to reduce its toxicity occurring at different levels within the human body, including the asbestosis-like toxicity to lung fibroblasts [41-46].

Among the different polymeric materials proposed for physical CNT functionalization, including proteins and polysaccharides, chitosan (CS) showed peculiar advantages because it coupled the advantages of high biocompatibility, chemical versatility, and tumor tissue affinity, with the easily processability in nanoparticle delivery systems suitable for administration via various routes, especially pulmonary [47-49]. CS possessed hydrophilic and cationic behaviors, being suitable for the surface functionalization of carboxylated CNT with the formation of nanocarriers stable in water solution [50,51]. Furthermore, due to its insolubility at pH 7.4 (physiological condition) and solubility in media with $\mathrm{pH}<6.5$ (tumor microenvironment), a $\mathrm{pH}-$ responsive behavior can be achieved [52-54], with the carrier able to retain the payload until reaching the target site with negligible early release.

Herein, we exploit the high lung affinity of CNT as a Trojan horse approach for delivering methotrexate (MTX) to the NSCLC. In detail, multi-walled carbon nanotubes (MWCNT) were functionalized with CS (CS_MWCNT), turning the weakness of CNT lung toxicity into the strength of a site-specific carrier with reduced side effects. The effectiveness of the proposed nanohybrids was assessed by extensive characterization of physico-chemical properties, and biological assays using NSCLC H1299 and MRC-5 cells, as models for NSCLC and healthy cells, respectively.

\section{Materials and Methods}

\subsection{Preparation of CS_MWCNT}

MWCNT were synthesized by fixed-bed chemical vapor deposition method, as reported in the literature [55].

For the oxidation procedure, $200 \mathrm{mg} \mathrm{CNT}$ were ultrasonicated in a mixture of $\mathrm{HNO}_{3}(65 \%)$ and $\mathrm{H}_{2} \mathrm{SO}_{4}(98 \%$ ) in the volume ratio 1:3 for $3 \mathrm{~h}$ [56]. Thereafter, the oxidized MWCNT (ox-MWCNT) were separated by filtration, washed with deionized water until solution neutrality, and finally dried at $108^{\circ} \mathrm{C}$ overnight [57].

For the fabrication of CS_MWCNT nanohybrid, $10 \mathrm{mg}$ ox-MWCNT in $5 \mathrm{~mL}$ acetic acid (5\%) was treated for $30 \mathrm{~s}$ with a sonication tip. Then, $25 \mathrm{mg}$ CS (wt 50,000-190,000 Da) was added and the mixture was stirred overnight at room temperature. Thereafter, it was filtrated and washed with $5 \%$ acetic acid and then with deionized water until solution neutrality. Finally, nanohybrid was dried at $40{ }^{\circ} \mathrm{C}$ overnight.

All chemicals were from Merck/Sigma Aldrich, Darmstadt, Germany.

\subsection{Characterization Procedure}

Scanning electron microscope images were acquired by a NOVA NanoSEM 200 [0-30 kV] (Thermo Fisher Scientific, Hillsboro, OR, USA) by depositing grounded samples onto self-adhesive, conducting carbon tape (Plano GmbH, Wetzlar, Germany). 
Transmission electron microscope images were acquired on HRTEM/Tecnai F30 [300 kV] (Thermo Fisher Scientific, Hillsboro, OR, USA) by pressing samples between two small slides of aluminum foil on a $\mathrm{Cu}$ TEM grid (200 mesh, Plano GmbH, Wetzlar, Germany).

$\mathrm{X}$-ray photoelectron spectroscopy spectra ( $0.8 \mathrm{eV}$ resolution) of samples prepared on an aluminum foil were performed using Al K $\alpha$ radiation on a XPS/PHI 5600-CI (Physical Electronics, Chanhassen, MN, USA).

Raman spectra ( $2 \mathrm{~cm}^{-1}$ resolution) were recorded on a Raman-Fourier transform spectrometer IFS 100 (Bruker Corporation, Ettlingen, Germany), operating at a wavelength of $633 \mathrm{~nm}$ with a laser power of $8 \mathrm{~mW}$. Samples were prepared by deposition on an aluminum foil.

Thermogravimetric analysis ( $~ 5.0 \mathrm{mg}$ samples) was performed in a Perkin-Elmer TGA-7 analyzer (Perkin-Elmer, Rodgau, Germany) under nitrogen atmosphere (flow of $100 \mathrm{~mL} \mathrm{~min}^{-1}$ ) and the following heating conditions: from 50 to $100{ }^{\circ} \mathrm{C}$ at $10^{\circ} \mathrm{C} \mathrm{min}^{-1}$; b) 30 min isothermal $100{ }^{\circ} \mathrm{C}$; from 100 to $275^{\circ} \mathrm{C}$ at $10^{\circ} \mathrm{C} \mathrm{min}-1 ; 30 \mathrm{~min}$ isothermal $275^{\circ} \mathrm{C}$; from 275 to $800{ }^{\circ} \mathrm{C}$ at $10^{\circ} \mathrm{C} \mathrm{min}^{-1}$.

\subsection{In Vitro MTX Release}

1.0 mg MTX (Merck/Sigma Aldrich, Darmstadt, Germany) was loaded on 10 mg CS_MWCNT in $10.0 \mathrm{~mL}$ distilled water by stirring at room temperature for $24 \mathrm{~h}$ and recovering the loaded sample (MTX@CS_MWCNT) after drying under vacuum.

The MTX release profiles were recorded by using, in separate experiments, release media consisting of phosphate buffered saline $\left(0.01 \mathrm{~mol} \mathrm{~L}^{-1}, \mathrm{pH} 7.4\right)$ or acetate buffer $\left(0.1 \mathrm{~mol} \mathrm{~L}^{-1}, \mathrm{pH} 5.0\right)$. In a standard procedure, MTX@CS_MWCNT (15 mg) was dispersed into $1.5 \mathrm{~mL}$ release media at the selected $\mathrm{pH}$ in a dialysis bag (MWCO: 12,000-14,000 Da, VWR International GmbH, Darmstadt, Germany), and dialyzed against $13.5 \mathrm{~mL}$ of the corresponding buffer. At predetermined time intervals, the amount of MTX in the releasing media was determined by HPLC analysis.

The HPLC system consisted of a Jasco BIP-I pump operating at a flow rate of $1.0 \mathrm{~mL} \mathrm{~min}^{-1}$ and Jasco UVDEC-100-V detector set at $306 \mathrm{~nm}$. A $250 \times 4 \mathrm{~mm} \mathrm{C-18} \mathrm{Hibar}{ }^{\circledR}$ column, $10 \mu \mathrm{m}$ particle size (Merck/Sigma Aldrich, Darmstadt, Germany) was used as stationary phase, while the mobile phase consisted of methanol: $0.05 \% \mathrm{w} / \mathrm{w} \mathrm{H}_{3} \mathrm{PO}_{4}$ (Merck/Sigma Aldrich, Darmstadt, Germany) aqueous solution $(23 / 77, \mathrm{vol} / \mathrm{vol})$.

\subsection{Cytotoxicity Tests}

Cell culture conditions were as follows. Roswell Park Memorial Institute (RPMI) medium supplemented with 10\% FBS and 1\% L-glutamate for human lung cancer cells H1299 (ATCC, In Vitro Technologies Pty. Ltd., Melbourne, Victoria, Australia); Eagle's Minimum Essential Medium supplemented with 10\% FBS for human lung fibroblasts cells MRC-5 (ATCC, In Vitro Technologies Pty. Ltd., Melbourne, Victoria, Australia). Both cell lines were grown as a monolayer in a humidified atmosphere at $37^{\circ} \mathrm{C}$ and in $5 \% \mathrm{CO}_{2}$.

Alamar Blue assay was used to assess effect of 48 h CS_MWCNT, MTX, and MTX@CS_MWCNT treatments. In a typical procedure, cells were plated in clear transparent 96-well plates $24 \mathrm{~h}$ prior to treatment, with the optimized cell density being $1.5 \times 10^{3}$ and $5 \times 10^{3}$ cells/well for H1299 and MRC-5, respectively. In all experiments, MTX concentrations (either in the free and in the loaded form) of $7.72 \times 10^{-5}$ and $1.51 \times 10^{-3} \mathrm{mg} \mathrm{mL}^{-1}$ were used, corresponding to CS_MWCNT concentrations of $7.72 \times 10^{-4}$ and $1.51 \times 10^{-2} \mathrm{mg} \mathrm{mL}^{-1}$, respectively.

All chemicals were purchased from Merck/Sigma Aldrich, Darmstadt, Germany.

\subsection{Cell Internalization Studies}

To prepare the samples for TEM analysis, human BCa cell line EJ28 (University of Frankfurt, Frankfurt, Germany) were seeded and incubated with $1.51 \times 10^{-2} \mathrm{mg} \mathrm{mL}^{-1}$ CS_MWCNT for $24 \mathrm{~h}$ in Eagle's Minimum Essential Medium. After co-incubation, the medium was removed and the cells were detached and fixed with $2 \%$ glutaraldehyde solution at $4{ }^{\circ} \mathrm{C}$. After washing, cells were dehydrated with 
increasing concentrations of acetone and embedded in a solution (50:50) of EPOXI resin. Then EPOXI resin was cut in $70 \mathrm{~nm}$ thin slices.

The samples were analyzed by transmission electron microscopy (TEM) using a FEI Tecnai T20 microscope (Thermo Fisher Scientific, Hillsboro, OR, USA) and operating at $200 \mathrm{keV}$.

\subsection{Statistical Analysis}

Experiments were carried out in triplicate. Values were expressed as means \pm standard error of the mean. For viability assay, statistical significance was assessed by two-way analysis of variance followed by post-hoc comparison test (Tukey's test). Significance was set at $p<0.01$.

\section{Results and Discussion}

\subsection{Material Properties}

The biological performance of a CNT nanohybrid strictly depends on its physic-chemical properties, which are in turn affected by either the organic or inorganic counterpart, opening a broad scenario for the development of engineered materials $[38,58]$. Thus, the selection of carbon nanostructures with appropriate behaviors is the main challenge to be addressed when designing high performing carrier systems [59,60].

It is well know that the synthetic and purification procedures play key roles in determining the CNT features, with the possibility to modulate the morphological patterns (e.g., size and number of shells), the electric and magnetic responses, the number of defects and density of branches, and the surface chemical affinity [61,62]. Here, we employed a fixed-bed chemical vapor deposition method, allowing us to produce well defined MWCNT with a narrower size distribution (length in a range of $110-980 \mathrm{~nm}$, average inner diameter of $0.7-1.5 \mathrm{~nm}$, and outer diameter of 5-8 nm corresponding to 4-7 graphene shells; see Figure 1a [63]) compared to MWCNT prepared by different techniques, such as aerosol assisted chemical vapor deposition (length in the range 10-30 $\mu \mathrm{m}$ and average outer diameter of 5-25 nm, corresponding to 20-30 graphene walls [64]). The significantly lower dimensional range allowed a more effective interaction with cell environment of lung, key requirement for an effective drug carrier [65].

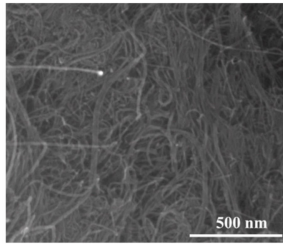

(a)

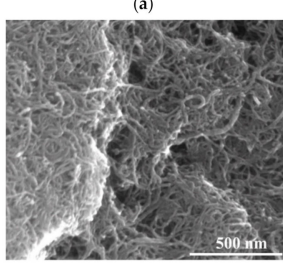

(d)

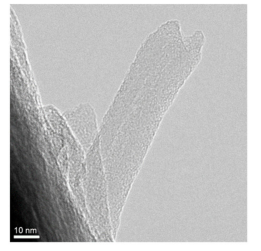

(b)

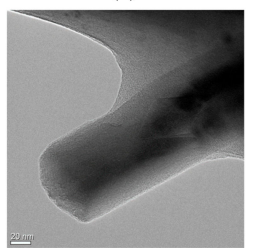

(e)

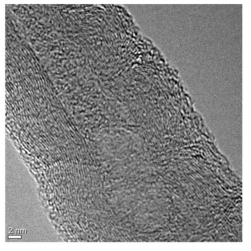

(c)

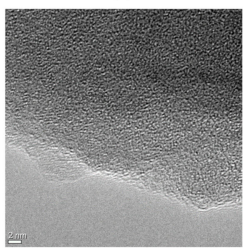

(f)

Figure 1. Representative SEM images of (a) multi-walled carbon nanotubes (MWCNT); (d) chitosan multi-walled carbon nanotubes (CS_MWCNT) and representative high-resolution transmission electron microscopic images of $(\mathbf{b}, \mathbf{c})$ MWCNT and $(\mathbf{e}, \mathbf{f})$ CS_MWCNT.

The synthetic protocol involved the preliminary MWCNT oxidation by means of $\mathrm{H}_{2} \mathrm{SO}_{4} / \mathrm{HNO}_{3}$ mixture in order to remove the residual catalyst and form $\mathrm{COOH}$ groups suitable for further functionalization.

We proposed a non-covalent coating of ox-MWCNT surface with a polysaccharide material such as CS, which is able to interact with the ox-MWCNT surface via either hydrophobic or hydrophilic interactions. In the first case, the C-C skeleton of sugar repeating units is connected with the $\mathrm{sp}^{2}$ carbon 
layer of CNT, while the amino and hydroxyl functionalities of CS are involved in the formation of electrostatic interactions and hydrogen bonds with the COOH of ox-MWCNT [66,67].

The effectiveness of each step was assessed by a multi-technique approach, involving morphological (combined SEM/TEM analysis) characterization, chemical analysis via X-ray photoelectron spectroscopy (XPS), investigation of vibrational characteristics and structural properties (Raman spectroscopy), and determination of thermal (Thermogravimetric analysis-TGA) features.

Pristine MWCNT show the typical structure with the presence of a few defects due to oxidation (Figure 1a-c), and the polymeric material around them being evident in the observation of the local structure of CS_MWCNT nanohybrid (Figure 1d-f).

Chemical analysis of samples was accomplished by XPS (Figure 2a). Pristine MWCNT shows only the carbon (C1s) signal (data not shown), while in CS_MWCNT hybrid, the oxygen (O1s) and nitrogen (N1s) signals are also recorded, giving another proof of the formation of nanohybrid. Furthermore, the C1s spectrum (Figure 2b) shows two main peaks, located at 284.5 and 285-290 eV, respectively. The first peak corresponds to the C-C and C-H components of either nanotubes and CS backbone [68,69], while the second broad band is assigned to $\mathrm{C}$ bonds (e.g., C-O, C-N) within the CS structure [69].

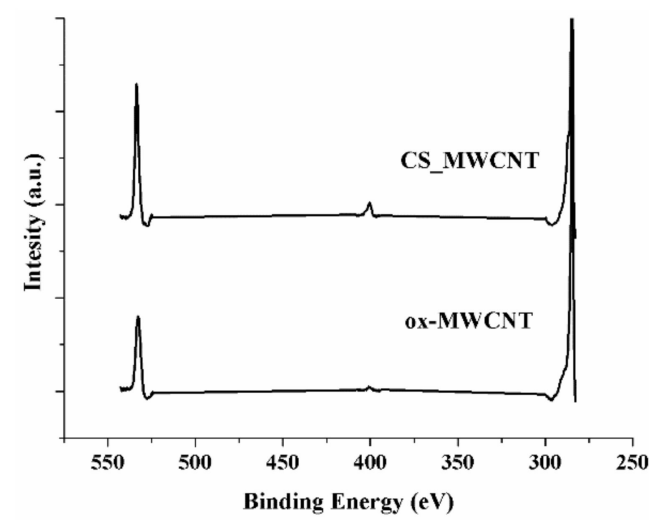

(a)

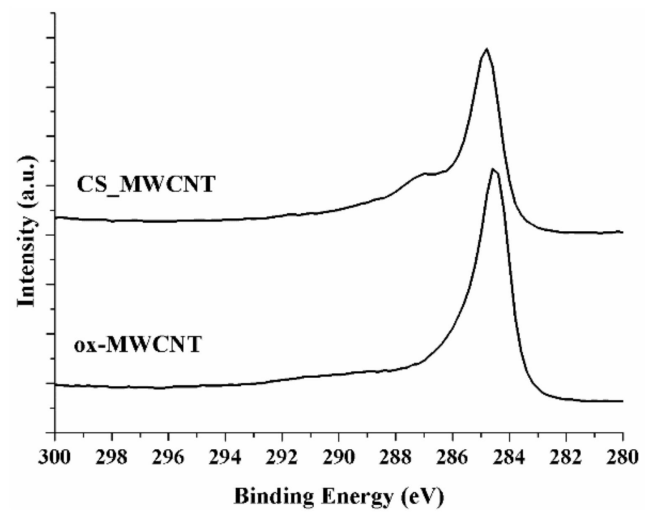

(b)

Figure 2. (a) XPS survey spectrum of ox-MWCNT, and CS_MWCNT; (b) XPS C 1s binding energy curves of ox-MWCNT, and CS_MWCNT.

The CS coating was also confirmed by Raman spectroscopy, with the Raman spectra of MWCNT showing the typical signals at 1346 and $1584 \mathrm{~cm}^{-1}$, corresponding to the D and $\mathrm{G}$ bands, respectively (Figure 3).

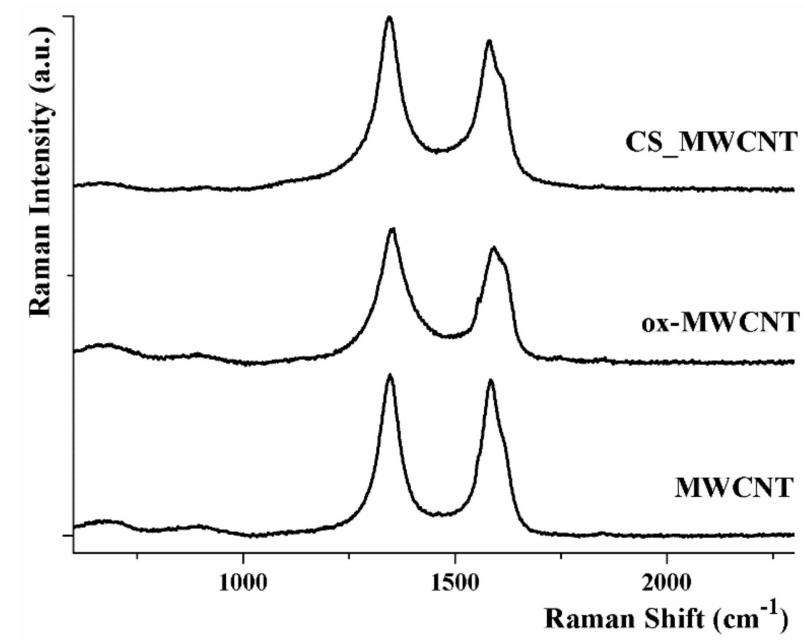

Figure 3. Raman spectra of MWCNT, ox-MWCNT, and CS_MWCNT. For all samples, D and G bands are located at 1347 and $1582 \mathrm{~cm}^{-1}$, respectively. 
D bands originated from disorder and distortions of the carbon network, while G (graphitic) bands corresponded to the tangential $\left(\mathrm{E}_{2 g}\right)$ stretching mode within the carbon $\mathrm{sp}^{2}$ in the CNT rolled graphene sheet [64].

The Raman patterns of ox-MWCNT and CS_MWCNT showed a similar behavior, although D and $G$ bands being in different relative ratios: the $\mathrm{I}_{\mathrm{G}} / \mathrm{I}_{\mathrm{D}}$ ratio of 0.96 recorded for pristine MWCNT became 0.86 for ox-MWCNT as a consequence of the increased defect sites (mainly $\mathrm{COOH}$ groups) upon oxidation. No further change in the $\mathrm{I}_{\mathrm{G}} / \mathrm{I}_{\mathrm{D}}$ ratio was recorded after $\mathrm{CS}$ coating, since the non covalent coating did not involve formation of new defects on ox-MWCNT surface.

The presence of CS coating was also evident by TGA measurements, because of the different thermal behavior of CNT and polymer counterparts (Figure 4).

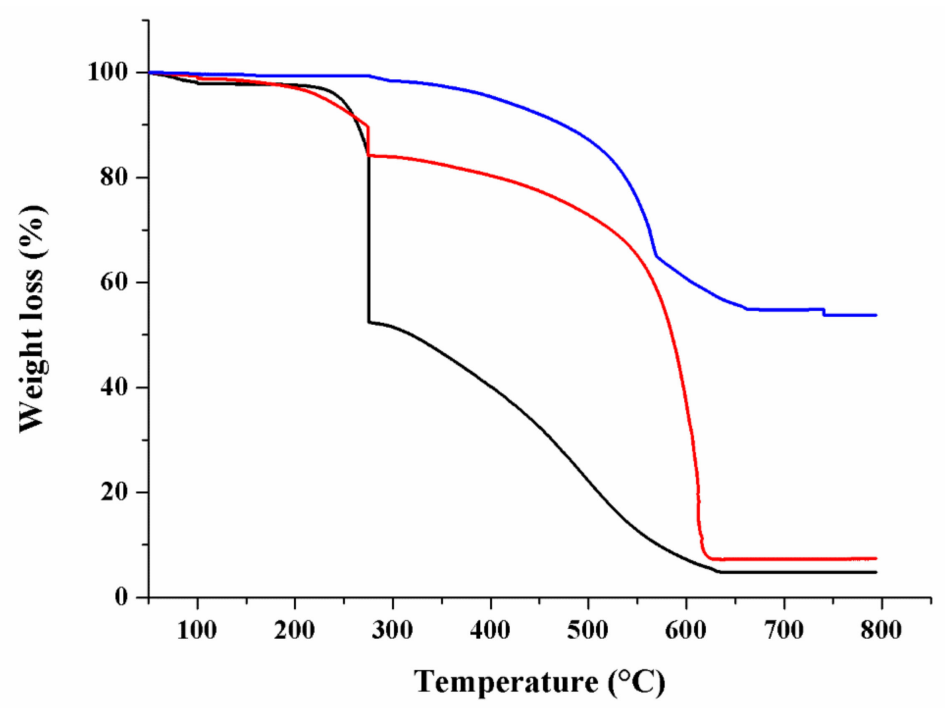

Figure 4. TGA thermograms of ox-MWCNT (blue line), CS (black line), and CS_MWCNT (red line) showing the effect of polymer coating on the thermal stability of hybrid samples.

In detail, the weight loss for pristine MWCNT was lower than $5 \%$ at $800{ }^{\circ} \mathrm{C}$ (data not shown), indicating the absence of relevant defect sites in the graphene layers. The oxidation process by means of acidic treatment $\left(\mathrm{HNO}_{3} / \mathrm{H}_{2} \mathrm{SO}_{4}\right.$ mixture) resulted in the creation of more defects sites, with a total weight loss of around $45 \%$ at $800{ }^{\circ} \mathrm{C}\left(\mathrm{CO}_{2}\right.$ loss) [70]. Pure CS showed two steps thermal degradation, corresponding to the amine side or $\mathrm{N}$-acetyl side groups $\left(275-290^{\circ} \mathrm{C}\right)$ and to the oxidative removal of the glycosidic linkage $\left(600-800{ }^{\circ} \mathrm{C}\right)$, respectively. The TGA curve of CS_MWCNT was similar to that of pure CS, with obvious lower weight loss due to the enhanced thermal stability due to MWCNT. From the difference in the weight losses, the amount of CS coating was calculated and found to be $20 \%$ [71].

\subsection{Drug Release Studies and In Vitro Anticancer Activity}

For the treatment of lung carcinomas, MTX (Figure 5) was found to possess high activity due to the strong inhibition of dihydrofolate reductase and folate receptor binding, but its clinical applicability is hindered by the development of multi-drug resistance, as well as from the insurgence of severe side effects to normal tissues and cells [72-74].

To date, many nanoparticle systems have been proposed for the vectorization of MTX with the aim to maximize the treatment effectiveness $[75,76]$. Here, the nanohybrid CS_MWCNT was designed as MTX delivery vehicle which, combining the $\mathrm{pH}$-responsivity of CS with the ability of MWCNT to be internalized rapidly within cells, was expected to vectorize MTX to cancer cells, thus reducing the side effects to normal cells. 
<smiles>CN(Cc1cnc2nc(N)nc(N)c2n1)c1ccc(C(=O)N[C@@H](CCC(=O)O)C(=O)O)cc1</smiles>

Figure 5. Chemical structure of methotrexate (MTX).

MTX was loaded by employing a drug to carrier ratio (by weight) of $10 \%$, and the release profiles recorded at $\mathrm{pH} 5.5$ and 7.4, simulating the endosomal $\mathrm{pH}$ of cancer cells, and the normal physiological $\mathrm{pH}$, respectively (Figure 6).

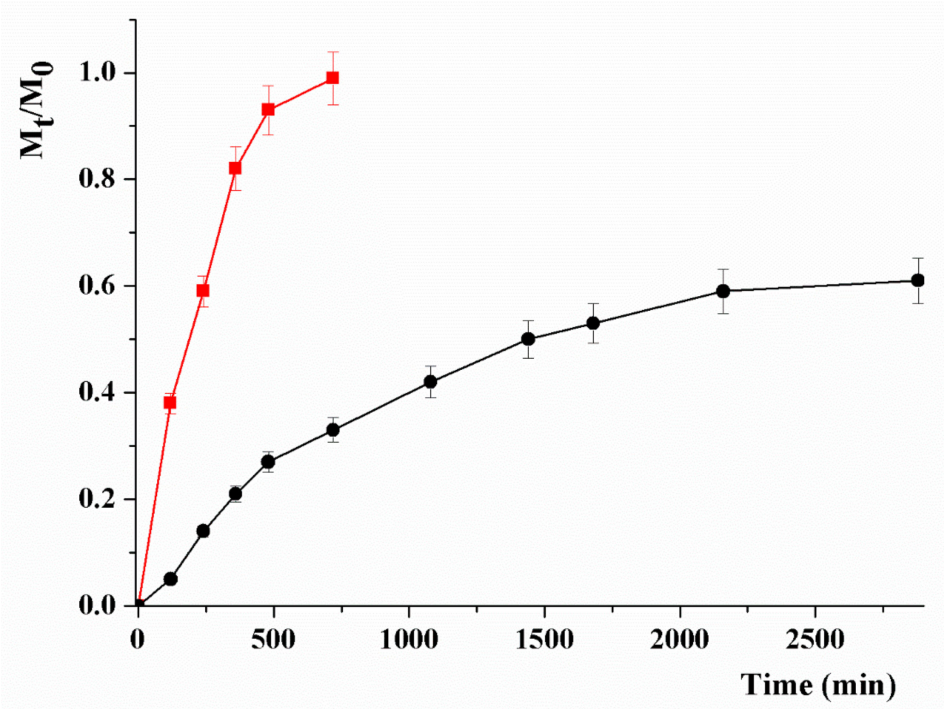

Figure 6. pH-responsive MTX release profile $\left(M_{t} / M_{0}\right)$ from CS_MWCNT at pH 5.0 (red line) and 7.4 (black line).

Mathematical modelling of the release profiles allowed us to better highlight the effect of $\mathrm{pH}$ on the physicochemical affinity of MTX between the carrier and the release media [77]. This phenomenon can be expressed by the $\alpha$ value calculated as follows (Equation (1)):

$$
\alpha=\frac{F_{\max }}{1-F_{\max }}
$$

where $F_{\max }$ represents the maximum value of relative release $\left(M_{t} / M_{0}\right)$.

By the employed kinetic model, the release profiles can be described according to the following Equations (2) and (3):

$$
\begin{aligned}
\frac{M_{t}}{M_{0}} & =F_{\max }\left(1-e^{-\left(\frac{k_{R}}{F_{\max }}\right) t}\right) \\
\frac{M_{t}}{M_{0}} & =\frac{F_{\max }\left(e^{2\left(\frac{k_{R}}{\alpha}\right) t}-1\right)}{1-2 F_{\max }+e^{2\left(\frac{k_{R}}{\alpha}\right) t}}
\end{aligned}
$$

with $k_{R}$ being the release rate constant.

When experimental data fit with Equation (2), reversible first-order kinetics can be evoked, while reversible second-order kinetics occur when Equation (3) is satisfied. 
In our conditions, higher $R^{2}$ values were obtained when Equation (2) is applied, suggesting release profiles with predominant first order kinetics (Table 1).

Table 1. $R^{2}$ values and kinetic parameters for mathematical modelling of MTX release.

\begin{tabular}{cccc}
\hline \multirow{2}{*}{ Mathematical Model } & Parameter & MTX \\
\cline { 3 - 4 } & & $\mathbf{p H ~ 5 . 0}$ & $\mathbf{p H ~ 7 . 4}$ \\
\hline \multirow{3}{*}{$\frac{M_{t}}{M_{0}}=F_{\max }\left(1-e^{-\left(\frac{k_{R}}{F_{\max }}\right) t}\right)$} & $R_{R}\left(10^{-3}\right)$ & 0.9906 & 0.9964 \\
& $F_{\max }$ & 4.31 & 0.66 \\
& $\alpha$ & 0.99 & 0.65 \\
& $t_{1 / 2}$ & 99 & 1.86 \\
& $R^{2}$ & 159 & 681 \\
\hline$M_{t}$ & $k_{R}\left(10^{-3}\right)$ & 0.9149 & 0.6959 \\
$F_{\max }\left(e^{2\left(\frac{k_{R}}{\alpha}\right) t}-1\right)$ \\
$1-2 F_{\max }+e^{2\left(\frac{k_{R}}{\alpha}\right) t}$ & $F_{\max }$ & 11.12 & 0.72 \\
& $\alpha$ & 0.99 & 0.70 \\
& $t_{1 / 2}$ & 99 & 0.33 \\
\hline
\end{tabular}

A highly remarkable $\mathrm{pH}$ responsivity was recorded, with a higher amount of MTX release at acidic $\left(F_{\max } \sim 1.0\right)$ vs. physiological $\left(F_{\max }=0.65\right) \mathrm{pH}$. Further information can be obtained by comparing the kinetic constants and the time required for reaching $50 \%$ of $F_{\max }\left(t_{1 / 2}\right.$ value, Equation (4)) in the two $\mathrm{pH}$ conditions:

$$
t_{1 / 2}=\frac{F_{\max }}{k_{R}} \ln 2
$$

This comparison better highlighted the $\mathrm{pH}$ responsivity, with the significant enhancement of the releasing rate at $\mathrm{pH} 5.0$ resulting in a four-fold reduction of the $t_{1 / 2}$ value, allowing a tumor specific delivery of the cytotoxic agent to be hypothesized.

This finding matched well with the results of cell viability studies performed selecting H1299 cells, NSCLC derived from the lymph node, and MRC- 5 cells, fibroblast derived from normal lung tissue, as models for cancer and physiological environments, respectively (Figure 7).

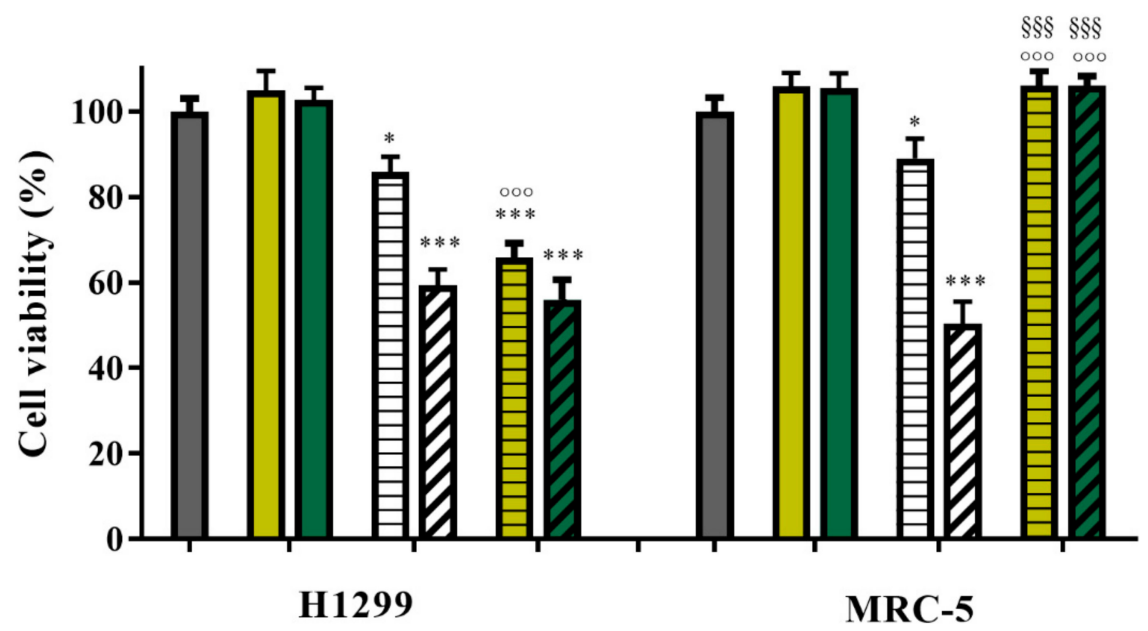

Figure 7. Cell viability of H1299 and MRC-5 cells after treatment with empty CS_MWCNT (filled bar), free MTX (empty streaked bar), and MTX@CS_MWCNT (filled streaked bar). MTX concentrations were $7.72 \times 10^{-5}$ (rowed bar) and $1.51 \times 10^{-3}$ (diagonal bar) $\mathrm{mg} \mathrm{mL}^{-1}$. CS_MWCNT concentrations were $7.72 \times 10^{-4}$ (light green bar) and $1.51 \times 10^{-2}$ (dark green bar) $\mathrm{mg} \mathrm{mL}^{-1}$. ${ }^{*} p<0.01,{ }^{* * *} p<0.0001$, vs. corresponding control; ${ }^{\circ \circ} p<0.0001$ vs. free MTX at equivalent concentration; $\S \S \S p<0.0001$ vs. same treatment on H1299 cells. 
In all experiments, MTX concentrations of $7.72 \times 10^{-5}$ and $1.51 \times 10^{-3} \mathrm{mg} \mathrm{mL}^{-1}$ and a fixed drug to carrier ratio of $10 \%$ (by weight) were employed, thus allowing us to calculate CS_MWCNT concentrations of $7.72 \times 10^{-4}$ and $1.51 \times 10^{-2} \mathrm{mg} \mathrm{mL}^{-1}$, respectively.

Empty CS_MWCNT was found to do not affect the viability of both cell lines, proving the key requirement of high biocompatibility of any carrier device. Free drug showed the expected concentration-dependent cytotoxicity, with the highest tested concentration resulting in a cell viability reduced to 59\% and 50\% in H1299 and MRC-5 cases, respectively. The similar effect of the drug on both cells lines is related to the specific metabolic features and high sensibility to almost any types of chemical species of MRC- 5 cells, which, indeed, have been recognized as a valid model for the classification and risk assessment studies of chemicals [78-80].

Interestingly, the loaded MTX@CS_MWCNT were found to be highly selective in killing cancer cells, with viability of health MRC-5 being not significantly $(p>0.01)$ affected by the treatments at the tested concentrations. In addition, MTX@CS_MWCNT were found to possess equal or even more activity than the free drug on cancer cells. At $7.72 \mathrm{mg} \mathrm{mL}^{-1}$, indeed, the $\mathrm{H} 1299$ viability was reduced by $15 \%$ when free MTX was used as treatment, while the loaded drug significantly $(p<0.0001)$ increased the amount of death cells up to $44 \%$. These results, related to the different metabolic rate of cancer and healthy lung cells, as well as to the different $\mathrm{pH}$ values of the two environment differently affecting the MTX release, clearly proved the in vitro efficiency of the CS_MWCNT nanohybrid.

The findings were also found to be in accordance with data in the literature showing that a slow release of cytotoxic drugs from nanocarrier systems is associated with a reduction of toxicity of loaded vs. free drug at equivalent concentrations [81,82]. Indeed, free MTX penetrated the cell membrane through passive diffusion, while a comparatively longer time was required for endocytosis-mediated internalization of MTX@CS_MWCNT [83-86]. As a proof of concept of this statement, and with the aim to extend the applicability of the proposed nanocarrier to different cancer cell lines, we investigated and proved the ability of CS_MWCNT to cross the cell membrane and be localized within the cytoplasm of EJ28 BCa cells (Figure 8).

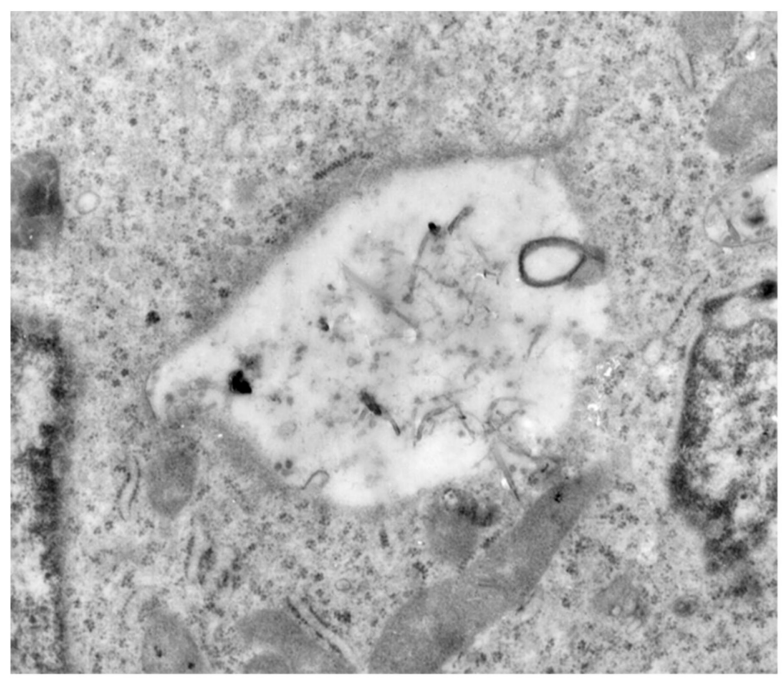

Figure 8. TEM images of EJ28 BCa cells after incubation with $1.51 \times 10^{-2} \mathrm{mg} \mathrm{mL}^{-1}$ CS_MWCNT, proving the presence of nanohybrid within the cytoplasm.

\section{Conclusions}

A novelCS_MWCNT nanohybrid was found to be suitable as a nanocarrier for the selective delivery of MTX to H1299 lung cancer cells, with negligible toxicity to healthy MRC-5 cells. The performance was related to the specific features of the nanohybrid, which possessed high biocompatibility and affinity for the drug, thus determining a sustained and $\mathrm{pH}$-responsive release profile. The extensive physic and chemical characterization of CS_MWCNT allowed us to highlight the correct assembly of organic 
and inorganic counterparts and the $\mathrm{pH}$ responsivity patterns. The in vitro biological characterization showed that, by taking advantage of the peculiar characteristics of lung cells, the nanoparticle carrier was able to synergize the drug activity in cancer cells, while reducing the toxicity of healthy ones.

The results of this study can be considered of great importance when hypothesizing the potential bench to clinic application of the proposed device, although further experiments should better elucidate the therapeutic performance in either different cancer cell lines or appropriate in vivo models, with the determination of the cross-applicability, the pharmacokinetics and toxicity profiles, as well as the ability to reduce tumor volume and prevent metastases.

Author Contributions: Conceptualization, G.C., O.V. and S.H.; Formal analysis, D.K., E.V., F.V., A.F., M.C. and U.G.S.; Funding acquisition, S.H.; Investigation, D.K., E.V., F.V., A.F., M.C. and U.G.S.; Methodology, G.C. and O.V.; Supervision, S.H.; Validation, G.C., O.V. and S.H.; Visualization, M.C.; Writing-original draft, G.C.; Writing-review \& editing, O.V. and S.H.

Funding: This study was supported by the German Cancer Aid (grant number 109617).

Conflicts of Interest: The authors declare no conflict of interest.

\section{References}

1. Zhou, J.; Sun, M.; Jin, S.; Fan, L.; Zhu, W.; Sui, X.; Cao, L.; Yang, C.; Han, C. Combined using of paclitaxel and salinomycin active targeting nanostructured lipid carriers against non-small cell lung cancer and cancer stem cells. Drug Deliv. 2019, 26, 281-289. [CrossRef]

2. Travis, W.D. Pathology of Lung Cancer. Clin. Chest Med. 2011, 32, 669-692. [CrossRef]

3. Oser, M.G.; Niederst, M.J.; Sequist, L.V.; Engelman, J.A. Transformation from non-small-cell lung cancer to small-cell lung cancer: Molecular drivers and cells of origin. Lancet Oncol. 2015, 16, e165-e172. [CrossRef]

4. Dela Cruz, C.S.; Tanoue, L.T.; Matthay, R.A. Lung Cancer: Epidemiology, Etiology, and Prevention. Clin. Chest Med. 2011, 32, 605-644. [CrossRef]

5. Chen, Z.; Fillmore, C.M.; Hammerman, P.S.; Kim, C.F.; Wong, K.K. Non-small-cell lung cancers: A heterogeneous set of diseases. Nat. Rev. Cancer 2014, 14, 535-546. [CrossRef]

6. Simon, G.R.; Wagner, H. Small cell lung cancer. Chest 2003, 123, 259S-271S. [CrossRef]

7. Guo, X.; Zhuang, Q.; Ji, T.; Zhang, Y.; Li, C.; Wang, Y.; Li, H.; Jia, H.; Liu, Y.; Du, L. Multi-functionalized chitosan nanoparticles for enhanced chemotherapy in lung cancer. Carbohydr. Polym. 2018, 195, 311-320. [CrossRef]

8. Chen, J.; Yang, X.; Huang, L.; Lai, H.; Gan, C.; Luo, X. Development of dual-drug-loaded stealth nanocarriers for targeted and synergistic anti-lung cancer efficacy. Drug Deliv. 2018, 25, 1932-1942. [CrossRef]

9. Spira, A.; Ettinger, D.S. Multidisciplinary Management of Lung Cancer. N. Engl. J. Med. 2004, 350, $379-392$. [CrossRef]

10. Weeks, J.C.; Catalano, P.J.; Cronin, A.; Finkelman, M.D.; Mack, J.W.; Keating, N.L.; Schrag, D. Patients' expectations about effects of chemotherapy for advanced cancer. N. Engl. J. Med. 2012, 367, 1616-1625. [CrossRef]

11. Hirsch, F.R.; Scagliotti, G.V.; Mulshine, J.L.; Kwon, R.; Curran, W.J.; Wu, Y.L.; Paz-Ares, L. Lung cancer: Current therapies and new targeted treatments. Lancet 2017, 389, 299-311. [CrossRef]

12. Chan, B.A.; Hughes, B.G.M. Targeted therapy for non-small cell lung cancer: Current standards and the promise of the future. Transl. Lung Cancer Res. 2015, 4, 36-54. [CrossRef]

13. Ettinger, D.S.; Wood, D.E.; Aisner, D.L.; Akerley, W.; Bauman, J.; Chirieac, L.R.; D'Amico, T.A.; Decamp, M.M.; Dilling, T.J.; Dobelbower, M.; et al. Non-small cell lung cancer, version 5.2017: Clinical practice guidelines in oncology. JNCCN J. Natl. Compr. Cancer Netw. 2017, 15, 504-535. [CrossRef]

14. Xu, M.; Asghar, S.; Dai, S.; Wang, Y.; Feng, S.; Jin, L.; Shao, F.; Xiao, Y. Mesenchymal stem cells-curcumin loaded chitosan nanoparticles hybrid vectors for tumor-tropic therapy. Int. J. Biol. Macromol. 2019, 134, 1002-1012. [CrossRef]

15. Zhang, G.; Mo, S.; Fang, B.; Zeng, R.; Wang, J.; Tu, M.; Zhao, J. Pulmonary delivery of therapeutic proteins based on zwitterionic chitosan-based nanocarriers for treatment on bleomycin-induced pulmonary fibrosis. Int. J. Biol. Macromol. 2019, 133, 58-66. [CrossRef] 
16. Loira-Pastoriza, C.; Todoroff, J.; Vanbever, R. Delivery strategies for sustained drug release in the lungs. Adv. Drug Deliv. Rev. 2014, 75, 81-91. [CrossRef]

17. Lerra, L.; Farfalla, A.; Sanz, B.; Cirillo, G.; Vittorio, O.; Voli, F.; Grand, M.L.; Curcio, M.; Nicoletta, F.P.; Dubrovska, A.; et al. Graphene oxide functional nanohybrids with magnetic nanoparticles for improved vectorization of doxorubicin to neuroblastoma cells. Pharmaceutics 2019, 11, 3. [CrossRef]

18. Kumari, P.; Ghosh, B.; Biswas, S. Nanocarriers for cancer-targeted drug delivery. J. Drug Target. 2016, 24, 179-191. [CrossRef]

19. Gurunathan, S.; Kang, M.H.; Qasim, M.; Kim, J.H. Nanoparticle-mediated combination therapy: Two-in-one approach for cancer. Int. J. Mol. Sci. 2018, 19, 3264. [CrossRef]

20. Kunz-Schughart, L.A.; Dubrovska, A.; Peitzsch, C.; Ewe, A.; Aigner, A.; Schellenburg, S.; Muders, M.H.; Hampel, S.; Cirillo, G.; Iemma, F.; et al. Nanoparticles for radiooncology: Mission, vision, challenges. Biomaterials 2017, 120, 155-184. [CrossRef]

21. Mehra, N.K.; Jain, A.K.; Nahar, M. Carbon nanomaterials in oncology: An expanding horizon. Drug Discov. Today 2018, 23, 1016-1025. [CrossRef]

22. Choi, K.Y.; Liu, G.; Lee, S.; Chen, X. Theranostic nanoplatforms for simultaneous cancer imaging and therapy: Current approaches and future perspectives. Nanoscale 2012, 4, 330-342. [CrossRef]

23. Lim, D.J.; Sim, M.; Oh, L.; Lim, K.; Park, H. Carbon-based drug delivery carriers for cancer therapy. Arch. Pharmacal Res. 2014, 37, 43-52. [CrossRef]

24. Teradal, N.L.; Jelinek, R. Carbon Nanomaterials in Biological Studies and Biomedicine. Adv. Healthc. Mater. 2017, 6, 1700574. [CrossRef]

25. Spizzirri, U.G.; Curcio, M.; Cirillo, G.; Spataro, T.; Vittorio, O.; Picci, N.; Hampel, S.; Iemma, F.; Nicoletta, F.P. Recent advances in the synthesis and biomedical applications of nanocomposite hydrogels. Pharmaceutics 2015, 7, 413-437. [CrossRef]

26. Wang, Y.; Liu, J.; Ma, X.; Liang, X.J. Nanomaterial-assisted sensitization of oncotherapy. Nano Res. 2018, 11, 2932-2950. [CrossRef]

27. Biagiotti, G.; Fedeli, S.; Tuci, G.; Luconi, L.; Giambastiani, G.; Brandi, A.; Pisaneschi, F.; Cicchi, S.; Paoli, P. Combined therapies with nanostructured carbon materials: There is room still available at the bottom. J. Mater. Chem. B 2018, 6, 2022-2035. [CrossRef]

28. Makharza, S.; Cirillo, G.; Bachmatiuk, A.; Vittorio, O.; Mendes, R.G.; Oswald, S.; Hampel, S.; Ruemmeli, M.H. Size-dependent nanographene oxide as a platform for efficient carboplatin release. J. Mater. Chem. B 2013, 1, 6107-6114. [CrossRef]

29. Marchesan, S.; Kostarelos, K.; Bianco, A.; Prato, M. The winding road for carbon nanotubes in nanomedicine. Mater. Today 2015, 18, 12-19. [CrossRef]

30. Lacerda, L.; Bianco, A.; Prato, M.; Kostarelos, K. Carbon nanotubes as nanomedicines: From toxicology to pharmacology. Adv. Drug Deliv. Rev. 2006, 58, 1460-1470. [CrossRef]

31. De Volder, M.F.L.; Tawfick, S.H.; Baughman, R.H.; Hart, A.J. Carbon nanotubes: Present and future commercial applications. Science 2013, 339, 535-539. [CrossRef]

32. Kesharwani, P.; Ghanghoria, R.; Jain, N.K. Carbon nanotube exploration in cancer cell lines. Drug Discov. Today 2012, 17, 1023-1030. [CrossRef]

33. Francis, A.P.; Devasena, T. Toxicity of carbon nanotubes: A review. Toxicol. Ind. Health 2018, 34, $200-210$. [CrossRef]

34. Yuan, X.; Zhang, X.; Sun, L.; Wei, Y.; Wei, X. Cellular Toxicity and Immunological Effects of Carbon-based Nanomaterials. Part. Fibre Toxicol. 2019, 16, 18. [CrossRef]

35. Aschberger, K.; Johnston, H.J.; Stone, V.; Aitken, R.J.; Hankin, S.M.; Peters, S.A.K.; Tran, C.L.; Christensen, F.M. Review of carbon nanotubes toxicity and exposure-appraisal of human health risk assessment based on open literature. Crit. Rev. Toxicol. 2010, 40, 759-790. [CrossRef]

36. Cirillo, G.; Hampel, S.; Spizzirri, U.G.; Parisi, O.I.; Picci, N.; Iemma, F. Carbon Nanotubes Hybrid Hydrogels in Drug Delivery: A Perspective Review. Biomed Res. Int. 2014, 2014, 825017. [CrossRef]

37. Zhou, L.; Forman, H.J.; Ge, Y.; Lunec, J. Multi-walled carbon nanotubes: A cytotoxicity study in relation to functionalization, dose and dispersion. Toxicol. In Vitro 2017, 42, 292-298. [CrossRef]

38. Adeli, M.; Soleyman, R.; Beiranvand, Z.; Madani, F. Carbon nanotubes in cancer therapy: A more precise look at the role of carbon nanotube-polymer interactions. Chem. Soc. Rev. 2013, 42, 5231-5256. [CrossRef] 
39. Vittorio, O.; Brandl, M.; Cirillo, G.; Spizzirri, U.G.; Picci, N.; Kavallaris, M.; Iemma, F.; Hampel, S. Novel functional cisplatin carrier based on carbon nanotubes-quercetin nanohybrid induces synergistic anticancer activity against neuroblastoma in vitro. RSC Adv. 2014, 4, 31378-31384. [CrossRef]

40. Di Leo, N.; Battaglini, M.; Berger, L.; Giannaccini, M.; Dente, L.; Hampel, S.; Vittorio, O.; Cirillo, G.; Raffa, V. A catechin nanoformulation inhibits WM266 melanoma cell proliferation, migration and associated neo-angiogenesis. Eur. J. Pharm. Biopharm. 2017, 114, 1-10. [CrossRef]

41. Kane, A.B.; Hurt, R.H.; Gao, H. The asbestos-carbon nanotube analogy: An update. Toxicol. Appl. Pharmacol. 2018, 361, 68-80. [CrossRef]

42. El-Gazzar, A.M.; Abdelgied, M.; Alexander, D.B.; Alexander, W.T.; Numano, T.; Iigo, M.; Naiki, A.; Takahashi, S.; Takase, H.; Hirose, A.; et al. Comparative pulmonary toxicity of a DWCNT and MWCNT-7 in rats. Arch. Toxicol. 2019, 93, 49-59. [CrossRef]

43. Chang, S.; Zhao, X.; Li, S.; Liao, T.; Long, J.; Yu, Z.; Cao, Y. Cytotoxicity, cytokine release and ER stress-autophagy gene expression in endothelial cells and alveolar-endothelial co-culture exposed to pristine and carboxylated multi-walled carbon nanotubes. Ecotoxicol. Environ. Saf. 2018, 161, 569-577. [CrossRef]

44. Otsuka, K.; Yamada, K.; Taquahashi, Y.; Arakaki, R.; Ushio, A.; Saito, M.; Yamada, A.; Tsunematsu, T.; Kudo, Y.; Kanno, J.; et al. Long-Term polarization of alveolar macrophages to a profibrotic phenotype after inhalation exposure to multi-wall carbon nanotubes. PLoS ONE 2018, 13, e0205702. [CrossRef]

45. Knudsen, K.B.; Berthing, T.; Jackson, P.; Poulsen, S.S.; Mortensen, A.; Jacobsen, N.R.; Skaug, V.; Szarek, J.; Hougaard, K.S.; Wolff, H.; et al. Physicochemical predictors of Multi-Walled Carbon Nanotube-induced pulmonary histopathology and toxicity one year after pulmonary deposition of 11 different Multi-Walled Carbon Nanotubes in mice. Basic Clin. Pharmacol. Toxicol. 2019, 124, 211-227. [CrossRef]

46. Nahle, S.; Safar, R.; Grandemange, S.; Foliguet, B.; Lovera-Leroux, M.; Doumandji, Z.; Le Faou, A.; Joubert, O.; Rihn, B.; Ferrari, L. Single wall and multiwall carbon nanotubes induce different toxicological responses in rat alveolar macrophages. J. Appl. Toxicol. 2019, 39, 764-772. [CrossRef]

47. Ali, A.; Ahmed, S. A review on chitosan and its nanocomposites in drug delivery. Int. J. Biol. Macromol. 2018, 109, 273-286. [CrossRef]

48. Jayakumar, R.; Menon, D.; Manzoor, K.; Nair, S.V.; Tamura, H. Biomedical applications of chitin and chitosan based nanomaterials-A short review. Carbohydr. Polym. 2010, 82, 227-232. [CrossRef]

49. Islam, N.; Dmour, I.; Taha, M.O. Degradability of chitosan micro/nanoparticles for pulmonary drug delivery. Heliyon 2019, 5, e01684. [CrossRef]

50. Dong, X.; Sun, Z.; Wang, X.; Zhu, D.; Liu, L.; Leng, X. Simultaneous monitoring of the drug release and antitumor effect of a novel drug delivery system-MWCNTs/DOX/TC. Drug Deliv. 2017, 24, 143-151. [CrossRef]

51. Li, B.; Zhang, X.X.; Huang, H.Y.; Chen, L.Q.; Cui, J.H.; Liu, Y.; Jin, H.; Lee, B.J.; Cao, Q.R. Effective deactivation of A549 tumor cells in vitro and in vivo by RGD-decorated chitosan-functionalized single-walled carbon nanotube loading docetaxel. Int. J. Pharm. 2018, 543, 8-20. [CrossRef]

52. Tang, D.L.; Song, F.; Chen, C.; Wang, X.L.; Wang, Y.Z. A pH-responsive chitosan-b-poly(p-dioxanone) nanocarrier: Formation and efficient antitumor drug delivery. Nanotechnology 2013, 24, 145101. [CrossRef]

53. Luesakul, U.; Puthong, S.; Neamati, N.; Muangsin, N. pH-responsive selenium nanoparticles stabilized by folate-chitosan delivering doxorubicin for overcoming drug-resistant cancer cells. Carbohydr. Polym. 2018, 181, 841-850. [CrossRef]

54. Muxika, A.; Etxabide, A.; Uranga, J.; Guerrero, P.; de la Caba, K. Chitosan as a bioactive polymer: Processing, properties and applications. Int. J. Biol. Macromol. 2017, 105, 1358-1368. [CrossRef]

55. Ritschel, M.; Leonhardt, A.; Elefant, D.; Oswald, S.; Büchner, B. Rhenium-catalyzed growth carbon nanotubes. J. Phys. Chem. C 2007, 111, 8414-8417. [CrossRef]

56. Tasis, D.; Tagmatarchis, N.; Bianco, A.; Prato, M. Chemistry of carbon nanotubes. Chem. Rev. 2006, 106, 1105-1136. [CrossRef]

57. Castro Nava, A.; Cojoc, M.; Peitzsch, C.; Cirillo, G.; Kurth, I.; Fuessel, S.; Erdmann, K.; Kunhardt, D.; Vittorio, O.; Hampel, S.; et al. Development of novel radiochemotherapy approaches targeting prostate tumor progenitor cells using nanohybrids. Int. J. Cancer 2015, 137, 2492-2503. [CrossRef]

58. Fabbro, C.; Ali-Boucetta, H.; Ros, T.D.; Kostarelos, K.; Bianco, A.; Prato, M. Targeting carbon nanotubes against cancer. Chem. Commun. 2012, 48, 3911-3926. [CrossRef] 
59. Augustine, S.; Singh, J.; Srivastava, M.; Sharma, M.; Das, A.; Malhotra, B.D. Recent advances in carbon based nanosystems for cancer theranostics. Biomater. Sci. 2017, 5, 901-952. [CrossRef]

60. Nasir, S.; Hussein, M.Z.; Zainal, Z.; Yusof, N.A. Carbon-based nanomaterials/allotropes: A glimpse of their synthesis, properties and some applications. Materials 2018, 11, 295. [CrossRef]

61. Pastorin, G. Carbon Nanotubes: From Bench Chemistry to Promising Biomedical Applications; CRC Press: Boca Raton, FL, USA, 2011.

62. Tavakolifard, S.; Biazar, E. Modification of carbon nanotubes as an effective solution for cancer therapy. Nano Biomed. Eng. 2016, 8, 144-160. [CrossRef]

63. Kaufmann, A.; Hampel, S.; Rieger, C.; Kunhardt, D.; Schendel, D.; Füssel, S.; Schwenzer, B.; Erdmann, K. Systematic evaluation of oligodeoxynucleotide binding and hybridization to modified multi-walled carbon nanotubes. J. Nanobiote. 2017, 15, 53. [CrossRef]

64. Cirillo, G.; Caruso, T.; Hampel, S.; Haase, D.; Puoci, F.; Ritschel, M.; Leonhardt, A.; Curcio, M.; Iemma, F.; Khavrus, V.; et al. Novel carbon nanotube composites by grafting reaction with water-compatible redox initiator system. Colloid Polym. Sci. 2013, 291, 699-708. [CrossRef]

65. Bhattacharya, K.; Mukherjee, S.P.; Gallud, A.; Burkert, S.C.; Bistarelli, S.; Bellucci, S.; Bottini, M.; Star, A.; Fadeel, B. Biological interactions of carbon-based nanomaterials: From coronation to degradation. Nanomed. Nanotechnol. Biol. Med. 2016, 12, 333-351. [CrossRef]

66. Ke, G.; Guan, W.; Tang, C.; Zeng, D.; Deng, F. Covalent functionalization of multiwalled carbon nanotubes with a low molecular weight chitosan. Biomacromolecules 2007, 8, 322-326. [CrossRef]

67. Bao, H.; Pan, Y.; Ping, Y.; Sahoo, N.G.; Wu, T.; Li, L.; Li, J.; Gan, L.H. Chitosan-functionalized graphene oxide as a nanocarrier for drug and gene delivery. Small 2011, 7, 1569-1578. [CrossRef]

68. Rasheed, A.; Howe, J.Y.; Dadmun, M.D.; Britt, P.F. The efficiency of the oxidation of carbon nanofibers with various oxidizing agents. Carbon 2007, 45, 1072-1080. [CrossRef]

69. Li, P.C.; Liao, G.M.; Kumar, S.R.; Shih, C.M.; Yang, C.C.; Wang, D.M.; Lue, S.J. Fabrication and Characterization of Chitosan Nanoparticle-Incorporated Quaternized Poly(Vinyl Alcohol) Composite Membranes as Solid Electrolytes for Direct Methanol Alkaline Fuel Cells. Electrochim. Acta 2016, 187, 616-628. [CrossRef]

70. Dong, X.; Liu, L.; Zhu, D.; Zhang, H.; Leng, X. Transactivator of transcription (TAT) peptide- chitosan functionalized multiwalled carbon nanotubes as a potential drug delivery vehicle for cancer therapy. Int. J. Nanomed. 2015, 10, 3829-3841. [CrossRef]

71. Carson, L.; Kelly-Brown, C.; Stewart, M.; Oki, A.; Regisford, G.; Luo, Z.; Bakhmutov, V.I. Synthesis and characterization of chitosan-carbon nanotube composites. Mater. Lett. 2009, 63, 617-620. [CrossRef]

72. Kim, N.H.; Kim, S.K.; Kim, D.S.; Zhang, D.; Park, J.A.; Yi, H.; Kim, J.S.; Shin, H.C. Anti-proliferative action of IL-6r-targeted antibody tocilizumab for non-small cell lung cancer cells. Oncol. Lett. 2015, 9, 2283-2288. [CrossRef]

73. Wang, M.; Yang, J.; Yuan, M.; Xue, L.; Li, H.; Tian, C.; Wang, X.; Liu, J.; Zhang, Z. Synthesis and antiproliferative activity of a series of novel 6-substituted pyrido [3,2-d] pyrimidines as potential nonclassical lipophilic antifolates targeting dihydrofolate reductase. Eur. J. Med. Chem. 2017, 128, 88-97. [CrossRef]

74. Qiu, Q.; Zhou, J.; Shi, W.; Kairuki, M.; Huang, W.; Qian, H. Design, synthesis and biological evaluation of N-(4-(2-(6,7-dimethoxy-3,4-dihydroisoquinolin-2(1H)-yl)ethyl)phenyl)-4-oxo-3,4-dihydrophthalazine1-carboxamide derivatives as novel P-glycoprotein inhibitors reversing multidrug resistance. Bioorganic Chem. 2019, 86, 166-175. [CrossRef]

75. Samorì, C.; Ali-Boucetta, H.; Sainz, R.; Guo, C.; Toma, F.M.; Fabbro, C.; Da Ros, T.; Prato, M.; Kostarelos, K.; Bianco, A. Enhanced anticancer activity of multi-walled carbon nanotube-methotrexate conjugates using cleavable linkers. Chem. Commun. 2010, 46, 1494-1496. [CrossRef]

76. Zhou, G.; Cheng, X.; Wu, S.; Jiang, X.; Shi, X.; Chen, J.; Zhang, J.; Zhao, J. Preparation and antitumor activity of a polymeric derivative of methotrexate. Am. J. Med Sci. 2012, 344, 294-299. [CrossRef]

77. Reis, A.V.; Guilherme, M.R.; Rubira, A.F.; Muniz, E.C. Mathematical model for the prediction of the overall profile of in vitro solute release from polymer networks. J. Colloid Interface Sci. 2007, 310, 128-135. [CrossRef]

78. Pasquier, E.; Street, J.; Pouchy, C.; Carre, M.; Gifford, A.J.; Murray, J.; Norris, M.D.; Trahair, T.; Andre, N.; Kavallaris, M. B-blockers increase response to chemotherapy via direct antitumour and anti-angiogenic mechanisms in neuroblastoma. Br. J. Cancer 2013, 108, 2485-2494. [CrossRef]

79. Mathes, S.H.; Ruffner, H.; Graf-Hausner, U. The use of skin models in drug development. Adv. Drug Deliv. Rev. 2014, 69, 81-102. [CrossRef] 
80. Di Luca, M.; Curcio, M.; Valli, E.; Cirillo, G.; Voli, F.; Butini, M.E.; Farfalla, A.; Pantuso, E.; Leggio, A.; Nicoletta, F.P.; et al. Combining antioxidant hydrogels with self-assembled microparticles for multifunctional wound dressings. J. Mater. Chem. B 2019, 7, 4361-4370. [CrossRef]

81. Ma, N.; Zhang, B.; Liu, J.; Zhang, P.; Li, Z.; Luan, Y. Green fabricated reduced graphene oxide: Evaluation of its application as nano-carrier for $\mathrm{pH}$-sensitive drug delivery. Int. J. Pharm. 2015, 496, 984-992. [CrossRef]

82. Bai, J.; Liu, Y.; Jiang, X. Multifunctional PEG-GO/CuS nanocomposites for near-infrared chemo-photothermal therapy. Biomaterials 2014, 35, 5805-5813. [CrossRef]

83. Barua, S.; Mitragotri, S. Challenges associated with penetration of nanoparticles across cell and tissue barriers: A review of current status and future prospects. Nano Today 2014, 9, 223-243. [CrossRef]

84. Lacerda, L.; Russier, J.; Pastorin, G.; Herrero, M.A.; Venturelli, E.; Dumortier, H.; Al-Jamal, K.T.; Prato, M.; Kostarelos, K.; Bianco, A. Translocation mechanisms of chemically functionalised carbon nanotubes across plasma membranes. Biomaterials 2012, 33, 3334-3343. [CrossRef]

85. Pogodin, S.; Baulin, V.A. Can a carbon nanotube pierce through a phospholipid bilayer? ACS Nano 2010, 4 , 5293-5300. [CrossRef]

86. Raffa, V.; Ciofani, G.; Vittorio, O.; Riggio, C.; Cuschieri, A. Physicochemical properties affecting cellular uptake of carbon nanotubes. Nanomedicine 2010, 5, 89-97. [CrossRef]

(C) 2019 by the authors. Licensee MDPI, Basel, Switzerland. This article is an open access article distributed under the terms and conditions of the Creative Commons Attribution (CC BY) license (http://creativecommons.org/licenses/by/4.0/). 